\title{
DOSSIER
}

\section{CINE, EDUCACIÓN Y PATRIMONIO CULTURAL}

\author{
Valeriano Duran Manso \\ Universidad de Cádiz, España \\ valeriano.duran@uca.es \\ Virginia Guichot \\ Universidad de Sevilla, España \\ guichot@us.es
}

\section{Introducción de editor invitado}

Una de las grandes renovaciones detectadas en las últimas décadas en la forma de hacer Historia se centra en las fuentes utilizadas por los historiadores/as; algo que guarda estrecha relación con la ampliación del concepto de patrimonio. En nuestra sociedad de la comunicación, en la que los mass media adquieren un enorme poder de socialización, parece casi inevitable recurrir a ellos como una fuente significativa para el estudio del pasado reciente. Su legado se enmarcaría dentro del denominado patrimonio cultural, que puede definirse como toda aquella manifestación humana, pasada o presente, tangible o intangible, a la que una colectividad reconoce como representativa de su identidad y vehículo de su memoria -histórica, social, cultural, ideológica (RODRÍGUEZ ORTEGA, 2011).

Ya en 1955, se formularon de la mano de Sir Arthur Elton las primeras teorías sobre el cine como patrimonio histórico. Este otorgó a los filmes la facultad de hacer historia, más allá de la simple escenificación del pasado. Es decir, el cine no sólo fue visto como reflejo de realidades sino como intérprete y creador de las mismas (o re-creador), poseedor del poder de configurar las representaciones mentales que sobre el pasado abrazaban los espectadores. Suponía un reconocimiento de la capacidad del cine como agencia constructora del imaginario social sobre aquellos temas que abordaba.

El valor patrimonial del cine obtuvo su primer reconocimiento oficial e internacional en 1981, mediante el documento Recomendación sobre la salvaguarda y la construcción de las imágenes en movimiento (RSCIM), elaborado por la UNESCO y aprobado en la XXI Sesión de la Conferencia General (Belgrado, 23 septiembre-29 octubre de 1980), pero habrá que esperar hasta 1995, con motivo de la celebración del centenario de la primera exhibición del cinematógrafo ante el público por los hermanos Lumière, para que la UNESCO defendiera por primera vez la necesidad de su conservación y recuperación, destacando, además, su 
potencial educativo por su carácter histórico y su papel de testigo en la evolución y cambio de la sociedad. Asimismo, la Unión Europea también ha elaborado una serie de documentos y promovido distintas iniciativas que destacan el valor patrimonial del cine, y reclama medidas dirigidas a su protección y difusión. En esta línea, se enmarcan, entre otros, el Convenio europeo para proteger el patrimonio audiovisual, que aprobó el Consejo de Europa en 2001; el informe sobre la Protección del Patrimonio Cinematográfico en Europa, publicado por el Observatorio Europeo del Audiovisual en 2004; y las Recomendaciones del Parlamento y del Consejo Europeo sobre el patrimonio filmico y la competitividad de las actividades industriales relacionadas, de 2005, entre otras.

Del mismo modo, desde hace varias décadas, seminarios, coloquios, congresos, cursos, proyectos de investigación... manifiestan el interés que despierta el cine entre los historiadores e historiadoras. No podía ser de otra forma cuando, tal como escribe Otero (2010), el cine contemporáneo nos muestra cómo es una sociedad, aunque los hechos que ahí se reflejan no reproduzcan sucesos fidedignos. En efecto, el cine, tanto en filmes de ficción como en documentales, nos da pistas significativas de cómo eran la política, la economía, la educación, el arte... y, en definitiva, la vida en etapas pasadas, o cómo se representaba en función de criterios políticos, religiosos o propagandísticos. Ostenta un papel relevante como testimonio y memoria social ya que es una expresión sociocultural de inestimable interés pedagógico y divulgativo. Ello posibilita el establecimiento de un discurso de conocimiento a través de la ficción (GISPERT, 2008).

Desde estas consideraciones, este monográfico se antoja oportuno por los estrechos vínculos existentes entre la educación y el cine, $\mathrm{y}$, especialmente, debido a las recientes normativas internacionales que destacan el valor patrimonial del considerado séptimo arte, su papel como testigo de la historia y la sociedad, y, por último, su capacidad para constituir memoria. Para ello, el dossier cuenta con las aportaciones de diversas personas investigadoras de las áreas de Historia de la Educación y de Comunicación Audiovisual, y de otras también afines a la Educación y a la Comunicación, procedentes de países como España y Brasil, y, en concreto, de las universidades de Cádiz, Vic, Málaga, Sevilla, La Coruña y Huelva, en el primer caso; y de la Pontíficia Universidade Católica de Campinas y de la Universidade Federal de Santa Catarina, en el segundo. Así, abordan variadas temáticas: el cine como patrimonio cultural y el trabajo de la Filmoteca Española; una propuesta de análisis fílmico en los documentales de los años veinte; la educación rural en el cine del Franquismo; la interpretación del pasado reciente español en el cine de la Transición; la representación cinematográfica de la multiculturalidad y la exclusión social en el aula actual; el aprendizaje 
de la pintura a través del cine; la deconstrucción de archivos en el cine reciente brasileño; y por último, los nuevos usos de los cines históricos de la ciudad de Joinville. De esta manera, el presente monográfico ofrece una reflexión sobre el tema desde diferentes y enriquecedoras perspectivas que se articulan en torno al cine, la historia, la educación, el patrimonio y los archivos.

\section{REFERENCIAS}

GISPERT, E. Cine, ficción y educación. Barcelona: Laertes, 2008.

OTERO URTAZA, E. Los jóvenes recluidos. Tres maneras cinematográficas de reflejar qué se aprendía en los internados del siglo XX. El cine como recurso metodológico en la docencia de Historia de la Educación. Cuadernos de Historia de la Educación, no 7, SEDHE, 2010, p.71-98.

RODRÍGUEZ ORTEGA, N. El patrimonio fílmico y cinematográfico. Cuestiones para una reflexión abierta. En: SAURET GUERRERO, T.; RUIZ SAN MIGUEL, J.; GÓMEZ GÓMEZ, A. J.; y CHAVES GUERRERO, E. I. (ed.): El cine español: arte, industria y patrimonio cultural. Málaga: Ministerio de Cultura, Instituto de Cinematografía y de las Artes Audiovisuales (ICAA) y Servicio de Publicaciones de la Universidad de Málaga, 2011, p.1528. 